\title{
Distribution of heat flux by working fluid in loop heat pipe
}

\author{
Patrik Nemec ${ }^{1, a}$ and Milan Malcho ${ }^{1}$ \\ ${ }^{1}$ University of Zilina, Faculty of Mechanical Engineering, Department of Power Engineering, Univerzitná 8215/1, 01026 Žilina, Slovakia
}

\begin{abstract}
The main topics of article are construction of loop heat pipe, thermal visualization of working fluid dynamics and research results interpretation. The work deals about heat flux transport by working fluid in loop heat pipe from evaporator to condenser evolution. The result of the work give us how the hydrodynamic and thermal processes which take place inside the loop of heat pipe affect on the overall heat transport by loop heat pipe at start-up and during operation.
\end{abstract}

\section{Introduction}

Infrared thermography is one of the most important sensing technologies applied to the detection and monitoring of manufacturing and production equipment. Until recently this sophisticated technology was prohibitively expensive, being driven primarily by military applications; over the last few years, however, the technology has improved and it has been introduced to high volume commercial and professional applications by innovative companies. This has brought the price down to a level which is opening up a host of new applications to use infrared thermography. One of new infrared thermograpy applications is thermal imaging heat flux transferred working fluid in heat pipes to verify and test heat pipe operation [1].

Heat pipe is device which is more and more used to heat transport industry branch, such as industries using thermal processes, heat transfer processes or in power electronics cooling, because use to heat transport latent heat contained in vapour at working fluid vaporization and thus significantly increases the heat pipe thermal conductivity.

The most cases of incorrect operation heat pipes is due to, carelessness in filling and sealing the heat pipe, wrong choice working fluid amount or the formation of non-condensable gas arising on account materials and working fluid incompatibility or impurities in the working fluid and materials of the heat pipe. These aspects affect the transferred heat flux which is reflected in the increase of the temperature difference between the evaporator and condenser part of the heat pipe. Scanning the surface temperature of the heat pipe during operation by infrared camera can be monitored transferred heat flux of the working fluid and thus determine whether the heat pipe working correctly. Some works deals about heat pipe experiments [2 - 4].

\section{Experiments}

In this section is described experiment of thermal imaging heat flux transferred working fluid in loop heat pipe by infrared camera. The experiment deals about influence of working fluid on heat transport ability of loop heat pipe and distribution of heat flux by working fluid.

\subsection{Loop heat pipe construction}

Loop heat pipe consists of an evaporator with wick, a condenser, a compensation chamber, and liquid and vapor line. Only the evaporator and the compensation contain wicks; the rest of the loop is made of smooth wall tubing. The wick in the evaporator is made with fine pores for purpose of developing a capillary pressure to circulate fluid around the loop, while the wick in the compensation chamber is made with larger pores for purpose of managing fluid ingress and egress. The operating principle of the LHP is as follows. As heat is applied to the evaporator, liquid is vaporized and the menisci formed at the liquid/vapour interface in the evaporator wick develop capillary forces to push the vapour through the vapour line to the condenser. Vapour condenses in the condenser and the capillary forces continue to push liquid back to the evaporator. The waste heat from the heat source provides the driving force for the circulation of the working fluid and no external pumping power is required. The two - phase compensation chamber stores excess liquid and controls the operating temperature of the loop [5].

\footnotetext{
${ }^{\mathrm{a}}$ Corresponding author: patrik.nemec@fstroj.uniza.sk
} 
This experiment was realized with loop heat pipe model made in our workplace. The loop heat pipe model is shown in figure 1 . In the figure 2 is cross section of compensation chamber and evaporator with capillary structure. The condenser of loop heat pipe model was created from finned pipe, so that heat loaded to the evaporator was dissipate to the ambient air by natural convection. The working fluid is acetone $(50 \%$ of loop heat pipe volume).

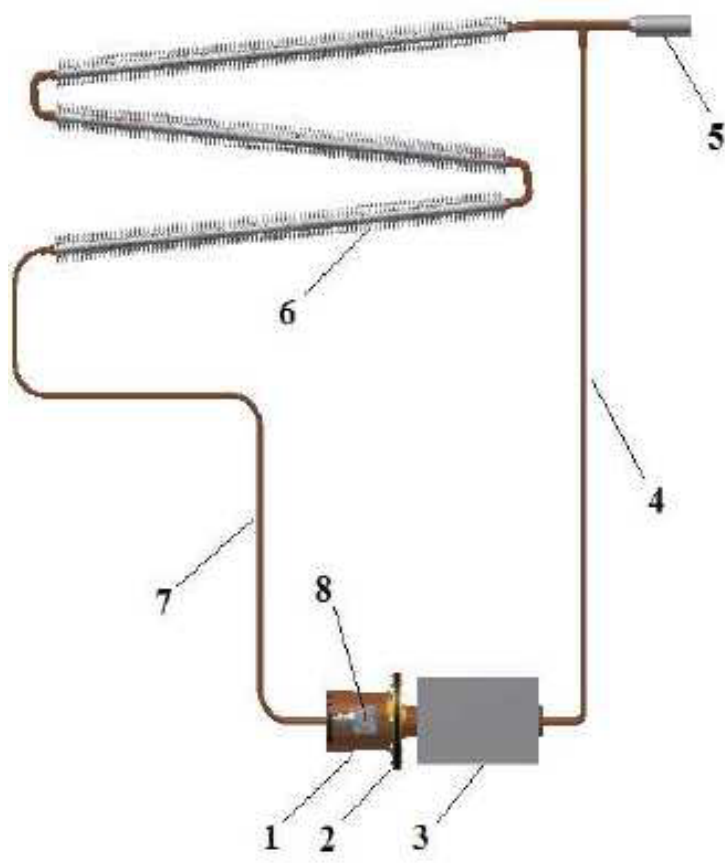

Figure 1. Model of loop heat pipe. 1 - compensation chamber, 2 - flange with isolation, 3 - evaporator, 4 - vapour line, 5 vent valve, 6 - condenser, 7 - liquid line, 8 - filling and closing valve.

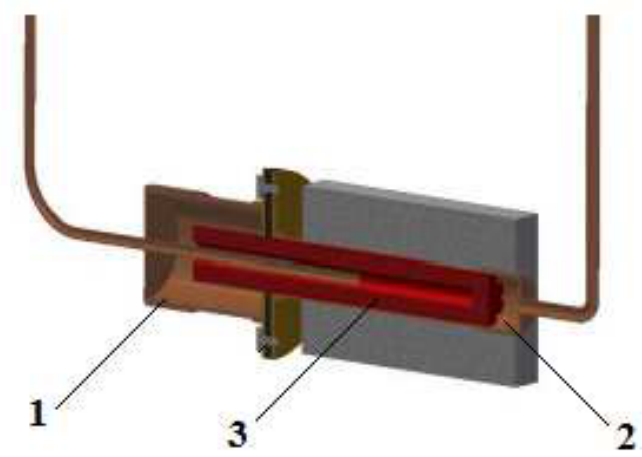

Figure 2. Cross section of compensation chamber and evaporator with capillary structure. 1 - compensation chamber, 2 - evaporator, 3 - capillary structure.

To achieve good thermal performance of loop heat pipe, capillary wicks with high permeability and porosity and fine pore radius are expected. These parameters depend mainly on the manufacturing process. The most frequently used wicks are made of sintered metal, like nickel, cooper, titanium, stainless steel or polymers (polyethylene, polypropylene, PTFE) [6]. There is known a number of research works which deal with sintered wick structure suitable in loop heat pipe $[7-11]$.
According [12] the main parameters of wick are porosity, pore diameter and permeability. The optimal porosity of sintered wick is between $30-75 \%$ regardless of the pore diameter. The sintered material porosity increases when the temperature or the forming pressure decrease. The optimal permeability is between $10^{-14}$ and $3.10^{-13} \mathrm{~m}^{2}$. The capillary structure used in loop heat pipe model shown in figure 3 was made from copper powder with granularity of $50 \mu \mathrm{m}$ by sintering in the electric oven.

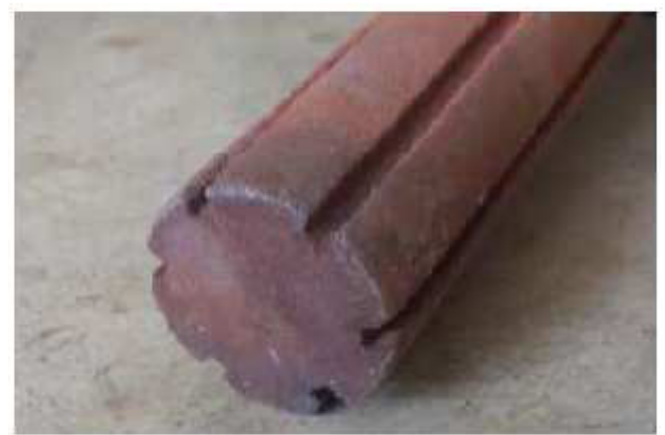

Figure 3. Capillary structure.

\subsection{Heat flux transport by working fluid in loop heat pipe}

In the figure 4 to 10 are shown thermal images of the loop heat pipe loaded by heat $60 \mathrm{~W}$ and heat flux distribution by working fluid at the time. On the first four thermal images is seen start-up of loop heat pipe, where is the heat flux gradually transferred by working fluid from evaporator to the condenser part. On the last two thermal images is see fully operated loop heat pipe without no temperature changes at time. There is seen different temperature between vapour line (on the right) and condenser line (on the left), too. The vapour line is hotter than the condensation line. It means that the vapours of the working fluid transfer all heat flux from evaporator (on the bottom) to the condenser (on the top). There vapours of the working fluid condense to the liquid, heat transferred from evaporator is removed to the surrounding and working fluid return back to the evaporator.

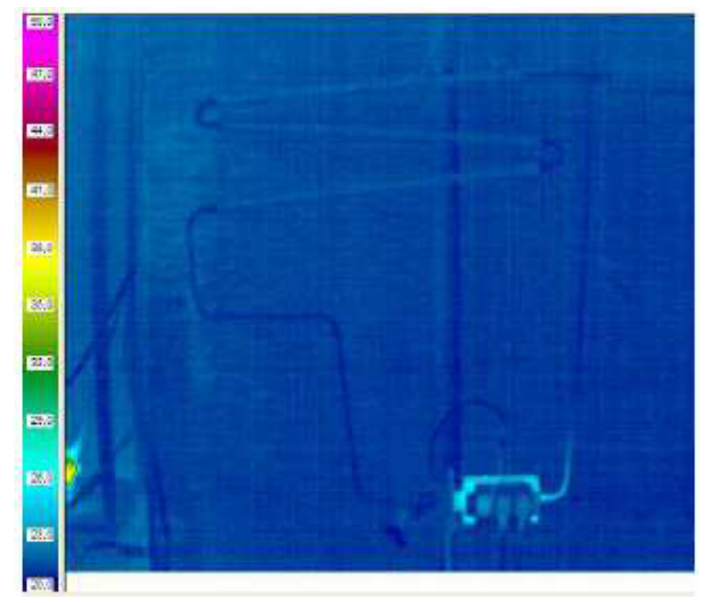

Figure 4. Surface temperatures develop of loop heat pipe at time 2 min from heating start. 


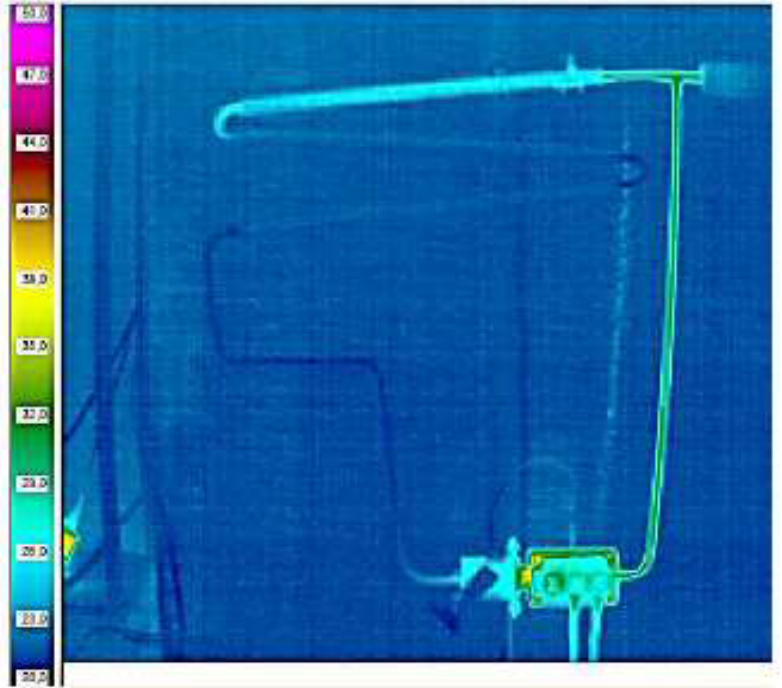

Figure 5. Surface temperatures develop of loop heat pipe at time 8 min from heating start.

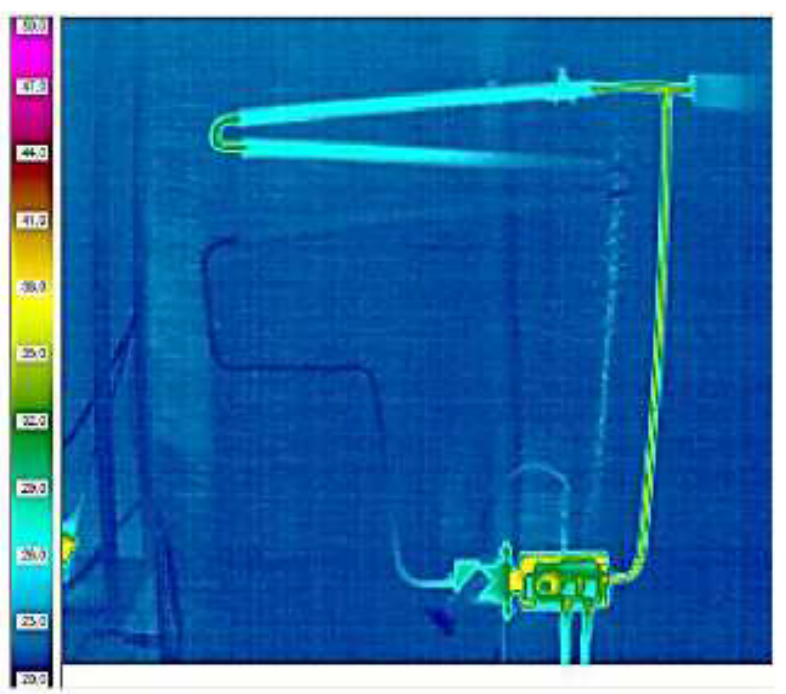

Figure 6. Surface temperatures develop of loop heat pipe at time $12 \mathrm{~min}$ from heating start.

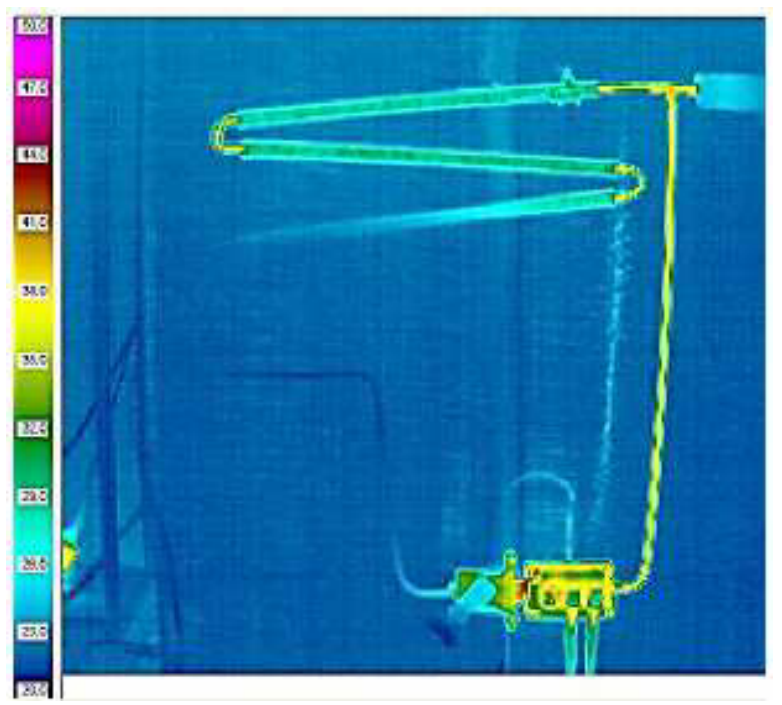

Figure 7. Surface temperatures develop of loop heat pipe at time 20 min from heating start.

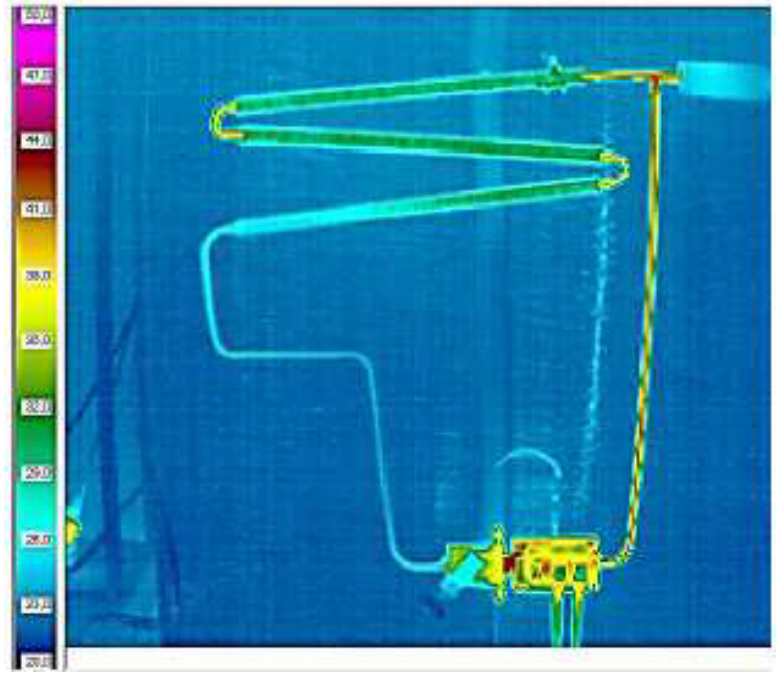

Figure 8. Surface temperatures develop of loop heat pipe at time $28 \mathrm{~min}$ from heating start.

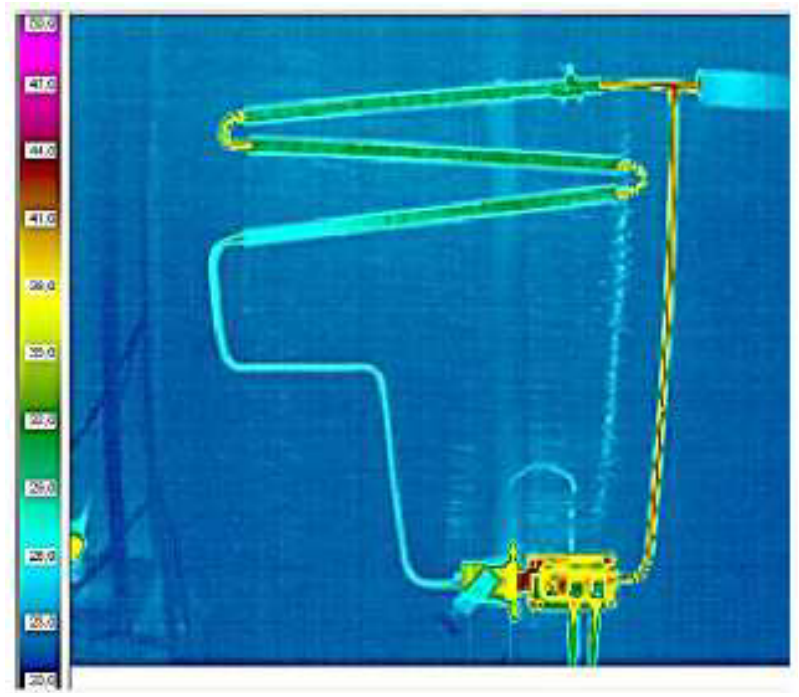

Figure 9. Surface temperatures develop of loop heat pipe at time $32 \mathrm{~min}$ from heating start.

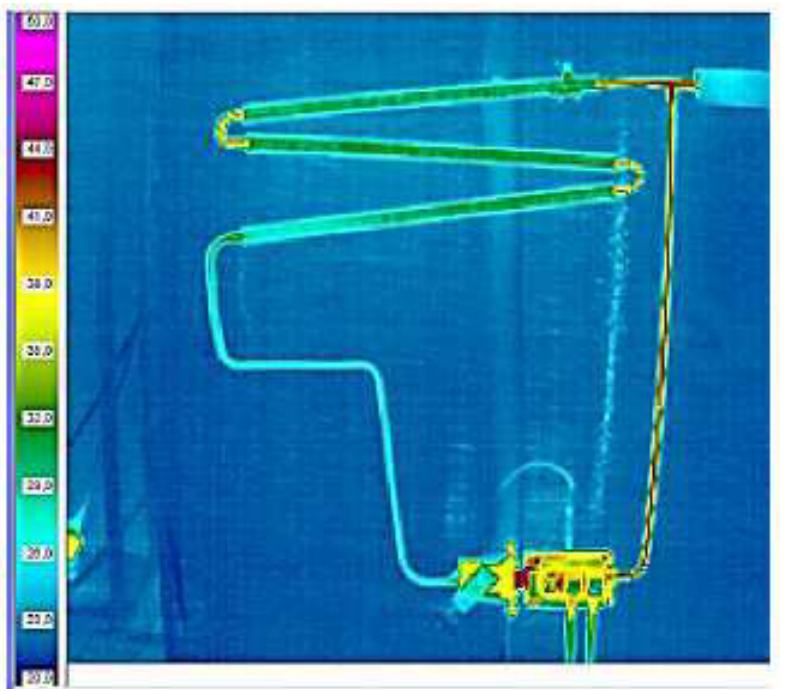

Figure 10. Surface temperatures develop of loop heat pipe at time $52 \mathrm{~min}$ from heating start. 


\section{Conclusions}

The goal of this work was design and construction of the loop heat pipe with possibility removed heat fluxes to the surrounding in range approximately of $50 \mathrm{~W}$. Thermal imaging of the loop heat pipe shows that the loop heat pipe loaded by heat $60 \mathrm{~W}$ has stabilized evaporator and condenser temperature after 30 minutes from start-up. Its operation was in equilibrium state without any temperature changes on evaporator and condenser part at time. This means that this loop heat pipe operate correctly and is able remove heat fluxes up-to $100 \mathrm{~W}$.

\section{Acknowledgment}

The research is supported by the European Regional Development Fund and the Slovak state budget for the project "Research Centre of University of Zilina", ITMS $26220220183(33 \%)$.

This work is supported by the financial assistance of the project APVV - 0577-10 "Cooling of power electronic systems by cooling cycles without mechanical drive" (34 \%).

The work is supported by Moderné vzdelávanie pre vedomostnú spoločnost'/Projekt je spolufinancovaný zo zdrojov EÚ. Podpora kvality vzdelávania a rozvoj l'udských zdrojov voblasti technického výskumu a vývoja v priestore modernej vedomostnej spoločnosti, ITMS 26110230117 (33\%).

\section{References}

1. A. Kapjor, T. Grešák, J. Hužvár, M. Vantúch, AIP Conf. Proc. 1608, 103-107 (2014)

2. R. Nosek, S. Gavlas, R. Lenhard, V. Sedlak, A. H. Mollerhagen, Communications. 16(3A), 62-66 (2014)

3. R. Lenhard, K. Kaduchová, Š. Papučík, J. Jandačka, EPJ Web of Conf. 67, 02067 (2014)

4. A. Čaja, M. Patsch, EPJ Web of Conf. 92, 02008 (2015)

5. J. Ku, $29^{\text {th }}$ Int. Conf. on Envir. Sys. (1999)

6. J. Li, Y. Zou, L. Cheng, R. Singh, A. Akbarzadeh, Pow. Tech. 204(2-3), 241-248 (2010)

7. T. Kaya, J. Ku, J. of Thermophys. and Heat Transf. 17(4), 464-470 (2003)

8. K. C. Leong, C. Y. Liu, G.Q. Lu, J. of Por. Mat. 4, 303-308 (1997)

9. E. G. Reimbrechta, M. C. Fredel, E. Bazzo, F. M. Pereira, Mat. Res. 2(3), 225-229 (1999)

10. N. J. Gernert, G. J. Baldassarre, J. M. Gottschlich, SAE Tech. Pap. 961319 (1996)

11. L. J. Orman, AIP Conf. Proc. 1608, 169-172 (2014)

12. S. Launay, V. Sartre, J. Bonjour, Int. J. Therm. Sci. 46, 621-636 (2007) 